\title{
Social Resilience of Rural Communities and Governance in Poverty Reduction
}

\author{
Bambang Noorsetya ${ }^{1}$, Chandra Dinata ${ }^{2 *}$, Umi Chayatin ${ }^{3}$ \\ \{dhiela_028@ymail.com ${ }^{1}$, chand.dinata@unmer.ac.id ${ }^{2}$, chayatin@gmail.com ${ }^{3}$ \} \\ University of Merdeka Malang, Indonesia ${ }^{1,}$ University of Merdeka Malang, Indonesia ${ }^{2}$ University of \\ Merdeka Malang, Indonesia ${ }^{3}$
}

\begin{abstract}
This article discusses the social resilience of rural communities in facing various kinds of problems that cause multidimensional poverty. Social resilience based on established social institutions provides new hope in the opening network access to strengthen the institutional capacity of the local economy so that a communal entity can be built out of poverty. The decentralization and autonomy practices imposed on the village government provide new nuances in realizing prosperity.
\end{abstract}

Keywords: Social Security; Poverty Reduction; Governance; Rural Communities; Decentralization.

\section{Introduction}

Poverty is still a trending topic in the repertoire of public administration thought, and efforts are made by the state to overcome it with various strategies and approaches. Development policies (economic, social, cultural, political, etc.) are a form of distribution of state authority in interpreting the "constitution" in solving public problems. For example, development policies in the economic sector are aimed at shaping and expanding the economic activities of a country in an effort to carry out its distributive function over all its resources for the purpose of welfare [1]. The aim of providing welfare for all levels of society is the most important part of a development policy by utilizing all of these resources. Economic experts and even policy experts argue that economic growth in general can benefit the poor through equitable distribution of resource use with development policies implemented by the state (Dollar \& Kraay, 2003; Bangura, 2015).

The implementation of development policies that are inversely proportional to the goal of leaving various social conditions in a country shows that the development formula is still undergoing a character building process in solving problems experienced by society. Basically, the social conditions arising from development policies lead to a process of "conquering" natural resources to improve the life of the people of a country with political and economic power (Townsend, 1987; Berger, 1992) for certain interests, especially in post-World War II which leads to control of economic resources (Rapley, 2007) so that the development paradigm is directed at changing the pattern of resource use in one country into an industrialized country 
(industrialization) in order to achieve a leap in economic growth so that poverty can be overcome by equitable distribution of employment through market expansion.

The development project launched through a policy to catch up (developed and developing countries) becomes a 'label' of development which results in the formation of classes in society, namely the proletariat (peasants) and the bourgeoisie (owners of capital) accompanied by the interests of each class for mastering resources in order to move the wheels of the economy (Berger, 1992; Brett, 2000; Ravallion, 2011; Ahluwalia, 1976; Cleaver, 2005; Ayub, 2013). Even development "claims" that can lead to class underdevelopment in a society resulting from poverty can be resolved by opening up market spaces (investors) who have more ability to manage resources owned by one country (modernization of resource management) and then distributed to the community. poor so that underdevelopment can be overcome [1]. A criticism of the development theory proclaimed by capitalist groups must of course be able to adapt to the local local culture, and must have a strong moral foundation embedded in development policies [11] if you want the success of a goal to deliver the poor from underdevelopment and economic, social, political, and cultural inequality in one country. Even the performance of economic development in several countries in Asia and Latin America, gender disparities and poverty are judged to be caused by development policies which are inversely proportional to the rate of capital investment from international business networks. Likewise with countries in Central and Eastern Europe that have made welfare policies the spearhead of economic performance, where development policies with industrialization of all aspects of society's needs are directed to provide welfare to their people [12].

The various arguments in explaining the scenario of unequal development in poverty alleviation by previously poor countries reflect the diversity of understanding of global poverty reduction. Even the prediction about the implementation of the MDGs that ended in 2015, there were many goals that were not achieved due to implementation challenges involving many stakeholders [13]. Even so, at least there are several approaches in reducing and overcoming poverty such as the health approach [14], religious approach (Senadjki \& Sulaiman, 2015; Sadeq, 1997), public spending approach [17], gender approach [18], micro economic development approach [19]. There are various approaches taken by the government in collaboration with the private sector, donor agencies, and civil society groups to tackle the problem of poverty. From all of these approaches, handling the problem of poverty always takes advantage of the local social potential to apply the principles of "from", "by" and "for" the poor. Social capital and social networks that are owned by one community group are a great force to encourage change from within that community group (Aldrich \& Meyer, 2015; De Luca \& Verpoorten, 2015; Rockenbauch \& Sakdapolrak, 2017) so that in the context of decentralization, poverty reduction can be realized with social capital owned by an entity of society as a communal movement that has full awareness of the problem of poverty that no longer relies on government intervention.

\section{Poverty Reduction in Public Administration Perspective}

In a theoretical context, issues of poverty in development become a serious problem that is studied by public administration experts. Poverty is the main domain in development policy, therefore there are at least three main theories in public administration that can be used to find theoretical meeting points for global poverty reduction efforts, especially in Indonesia. The three major theories are Government, Public Policy, and Public Management, each of which has a "structure" and "superstructure" domain that is formed to formulate an understanding of poverty alleviation. Poverty has become a global issue so that the leaders of developing countries as well as developing developed countries have formulated a global framework for poverty alleviation, 
so that the idea of the MDGs was born, which in 2015 developed a new strategy for poverty alleviation through the SDGs. As an effort to carry out these poverty alleviation programs, governments in a country have a major role in achieving global targets for poverty alleviation.

Through its three theories, public administration becomes a logical consequence in scientific development that plays a role in efforts to alleviate poverty, each theory makes contact with other theories in state administration, therefore theoretical problems arise in the context of poverty reduction. Therefore, the theoretical allusion to public administration for poverty alleviation can be illustrated in the following figure:

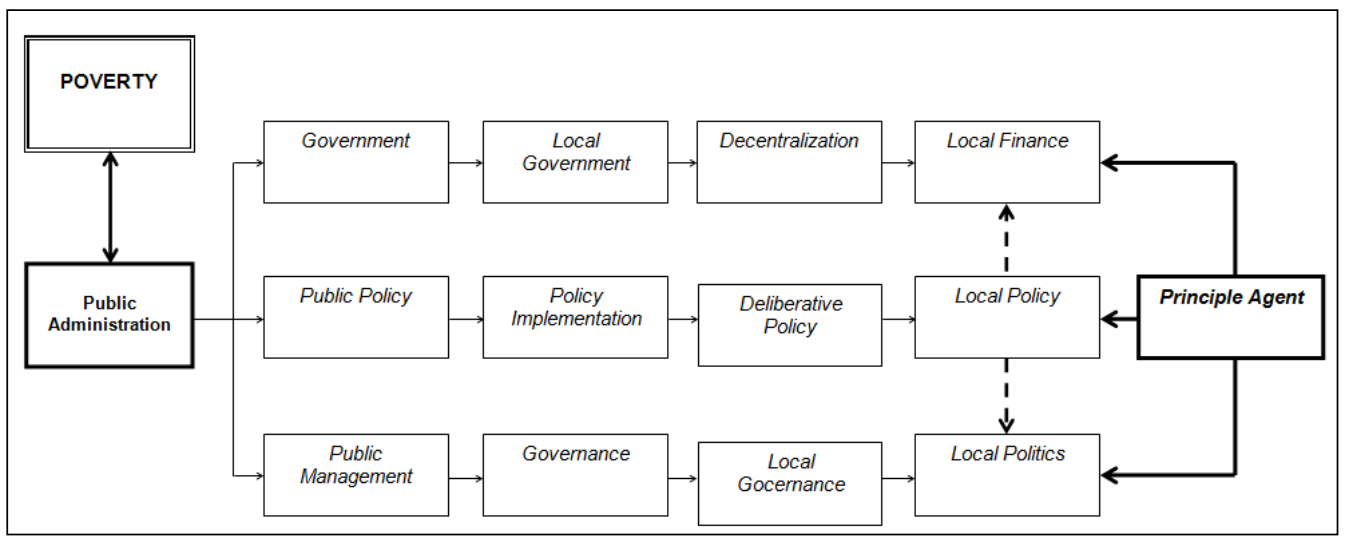

Fig. 1. Skema Teoritik Pengentasan Kemiskinan dalam Persepektif Administrasi Publik

The theoretical illustration above provides an overview of the role of public administration in its development to alleviate poverty. Literally, public administration aims to provide services to the public rationally through policies made by the government to solve public problems (Vries, 2016). In the conception built by Vries (2016) that the state is a collection of people who occupy certain areas and are organized by the government and have sovereignty. Meanwhile, the government is an organization that has the authority to formulate the legal framework and its implementation mechanism (rule of the law), and government includes all organs consisting of all apparatus as a means of completing the state in carrying out all activities in the efforts to achieve the goals of the state (Vries, 2016). So, it can be explained: First, the theory of government in poverty alleviation explains the structuring of government structures (bureaucracy). Then public policy is used as an instrument for the government to solve public problems, especially the problem of poverty (pro poor policy). Meanwhile, public management is a government instrument in developing a framework for basic services provided by the government to the community, especially for the poor. Second, from the structuring carried out, the needs for local structures that have their own characteristics are the basic building blocks for local government, so that structural innovation based on needs was born from the concept of decentralization. Kemudian dari desentralisasi dengan inovasi strukturalnya diharapkan mampu menyusun anggaran public yang berpihak kepada masyarakat miskin (pro poor budgeting) dalam konsep local finance. Third, another section on public policies that are able to solve poverty problems by implementing a commitment to poverty alleviation (policy implementation) by utilizing local resources and their networks (deliberative policy) so that innovation in poverty reduction policies (local policy) can be realized. Fourth, public management in providing access to basic services for the poor is a form of government commitment in efforts to alleviate poverty which is a common problem, therefore 
multistakeholders are involved through the concept of governance. Thus, the strengths of local institutions can be used as reinforcement of government policies (local governance) in the agenda of poverty alleviation adjusted to the dynamics of local politics as a characteristic of poverty reduction policies. And the fifth, in the context of implemented local policies for poverty alleviation, the logical consequence is the budgeting and financing of these programs. Because the local government utilizes and involves local institutions and local networks in poverty alleviation, the local political dynamics will become an obstacle to policy innovation carried out in poverty alleviation programs. Therefore, as a theoretical offer, the principle agent theory can be used as a reinforcement and at the same time balancing the gap between "local finance, local policy, and local politics" which can build change based on local ideas and local values (Hoadley, 2006).

\section{Finding and Discussion}

The results presented are data obtained from research in Malang Regency. Resourches that are owned economically are basically able to encourage community groups to work together with the government in reducing the local poverty rate, especially poverty in rural communities. However, the problem of poverty still cannot be maximally resolved. The high poverty rate in Malang Regency which reaches 246,600 (people) and in rural areas contributing to poverty reaching $15.58 \%$ or $2,949.82$ thousand poor people is a problem that requires seriousness in overcoming steps quickly. Basically, many programs and activities implemented by the government have been carried out in the context of poverty alleviation, both of which are programs sourced from the APBN and APBD which are used as pioneers in efforts to reduce poverty and economic disparities in society, especially in rural communities. There are driving factors that cause poverty in rural areas in Malang Regency, namely: 1). Low level of community welfare; 2 ). Limited employment opportunities in the place of origin, such as due to the entry of agricultural technology in rural areas; 3). There is a culture of discrimination resulting from patron-client and patriarchal practices; 4). Reasons for work or marriage at an early age; 5). The existence of annual disasters such as floods; 6). The ethnography of a large area and its different economic bases; 7). Low level of innovation and community achievement; and 8). Highest stunting. All of these driving factors have pull factors that cause poverty in the regions, among others: first. High birth rates in Malang; second, the number of villages as pockets of poverty; and third. The gap between regions is still high.

Broadly speaking, poverty is actually caused by internal factors that cause a person to be in the poverty line, and is used as a development problem which has a negative impact on imbalance in economic growth, and can also widen the income gap between people and the income gap between regions (inter-region income gap) so that there are 8 (eight) problems faced by the Malang Regency government in poverty reduction, namely: 1). Weak government institutions in poverty reduction; 2). The available data on poor families is not sufficient / updated so that the Government has not maximally evaluated its policies; 3). Budget support for poverty alleviation that is still limited and has not synergized; 4). Limited field officers or human resources in community empowerment; 5). Not yet actively and optimally involved community groups in the poverty alleviation program that has been launched; 6). Low community motivation which has an impact on community participation in poverty alleviation programs; 7). There are still many mal-administrative actions in the distribution of central and provincial 
policy programs; and 8). The high dependence of the community on the government subsidy program.

Poverty alleviation is part of the community empowerment program effort which has been a policy trend or bafer policy so far. The community empowerment strategy that has been synonymous with top down or systemized programs comes from central government programs, where these programs are often ineffective in implementing their programs, therefore they need to be used as material for re-evaluation of any centralized government program so as not to fail in addressing local poverty problems in rural areas that are seen as requiring innovative program governance in reducing poverty through a quadruple helix approach [23] by relying on the social resilience of rural communities. Quadruple helix as a user-oriented innovation approach that focuses strongly on collaboration in innovation and, in particular, processes that are dynamically interwoven with rational institutions. Innovations carried out by using the social capital of rural communities, coupled with networks built by the community, government and the private sector, are able to independently strengthen the community's economic resources.

The quadruple helix perspective as a network in modeling poverty alleviation in rural areas is based on a pattern of relationships that are built across actors with buttom up and overlapping patterns by upholding social resilience, as public and private organizations interact in the process of creating value values to convert various inputs into outputs. valuable for the government organizationally and institutionally as well as for the community itself with the principle of effectiveness and efficiency of its resources. The pattern applied rests on relational processes as regulated in the quadruple helix arrangement, namely the actors (public and private) involved, the combined resources, and the activities carried out, and the results of the process, namely the value received by the actors involved in a network of relationships. A society with social life characteristics dominated by strong kinship generates sufficient social resilience in building relationships with the government and the private sector in managing social and economic resources to promote communal economic quality. Community independence can be seen from the managerial power of the resources independently by the community [24] so that they are able to exclude rural groups from the poverty zone.

As an institution, the system of governance in dealing with poverty problems is decentralized and is given autonomous authority to rural communities which is a sub system of village government. The buttom up pattern in the effort to alleviate poverty places the role and function of community social institutions to serve as the glue for communalism so that the issue of poverty becomes a shared responsibility. From this pattern, the social resilience of the community in the implementation of the quadruple helix is formed by an integrative and collaborative hybrid organization that can stimulate innovation in poverty reduction in rural communities.

The involvement of key stakeholders in the context of the quadruple helix which is based on social resilience such as the government, private sector, community and academics in an effort to empower and manage resources owned by rural communities is aimed at improving the quality of life of the community. There is a unity of vision and mission of all multi actors in an effort to improve the quality of life of rural communities who always rely on social capital so that the government with its hybrid organization is intense in communicating with various parties. Acadmission actors are part of conceptual development through Resaech and Development so that an innovation is formed. Then the private actor plays a role in initiating aspects of innovation and emphasizes innovation to stimulate multi-effects on the lives of rural communities. Whereas community actors become objects that are empowered by maintaining local wisdom as a source of social resilience through social institutions so that having a spirit of full autonomy can be absorbed in the village government hybrid organization. 
The occurrence of multi-dimensional poverty must be handled multi-perspective by involving various stakeholders in one command. The social capital owned by rural communities has been used for generations as a social force so that the management of the community's economic resources can be maintained and can even be developed if the social structure is used as the object of development of the autonomous system of hybrid governance so that it is closely related to networks, knowledge transfer, and human capital [25] in strengthening a social entity by developing the selling value of products produced from local resources. Herein lies the importance of social resilience in strengthening social entities to encourage togetherness in dealing with poverty problems in the regions.

\section{Conclution}

Poverty in Indonesia is dominated by the economic structure of rural communities. It is not surprising that the contribution to the poverty rate is dominated by rural communities. A different life from urban communities which can be seen from the system of governance of economic resources. If rural communities manage economic resources traditionally and prioritize the social sphere, while urban communities manage their economic resources in a modern way, and industries develop in cities by prioritizing economic principles. The uniqueness of the lifestyle lived by rural communities who live with social forces from generation to generation so that the spirit of communalism in rural communities is much stronger than that of urban communities. The same goes for poverty alleviation.

Large resources managed autonomously by the regional government are directed at efforts to tie the quality of people's lives so that the problem of poverty in the regions can be overcome. The hybrid organizational pattern of placing local institutions with owned social capital can be manifested in village governance. Of course, in an effort to overcome the problem of poverty in rural communities, the management of local resources can be carried out using a quadruple helix model that relies on the social resilience of the community so that the social institutions of rural communities can function and can be used as a reinforcement for the success of programs launched by the government.

The traditional pattern adopted by rural communities in managing their economic resources is maintained by fostering a spirit of togetherness so that institutionalized communalism is born, especially in poverty reduction. Rural communities must be placed as subjects, not objects of top-down development programs. Thus, if the hybrid organization formed from the village government and the economic resource development program is carried out with a quadruple helix model that emphasizes local wisdom, innovation in developing the potential of the community can be carried out, so that the factors that cause poverty in rural communities will be overcome. 


\section{References}

[1] R. Kanbur, "Economic policy, distribution and poverty: The nature of disagreements," World Dev., 2001, doi: 10.1016/S0305-750X(01)00017-1.

[2] D. Dollar and A. Kraay, "Institutions, trade, and growth," J. Monet. Econ., 2003, doi: 10.1016/S0304-3932(02)00206-4.

[3] Y. Bangura, "Developmental Pathways to Poverty Reduction," in Developmental Pathways to Poverty Reduction, 2015.

[4] P. Townsend, "Conceptualising Poverty," Dyn. Deprivation, Aldershot Gower, 1987.

[5] G. Berger, "Social structure and rural development in the Third World," Soc. Struct. Rural Dev. Third World, 1992, doi: 10.5860/choice.31-0610.

[6] E. A. Brett, "Development theory in a post-socialist era: Competing capitalisms and emancipatory alternatives," J. Int. Dev., 2000, doi: 10.1002/10991328(200008)12:6<789::AID-JID715>3.0.CO;2-S.

[7] M. Ravallion, "On multidimensional indices of poverty," J. Econ. Inequal., 2011, doi: 10.1007/s10888-011-9173-4.

[8] M. S. Ahluwalia, "Inequality, poverty and development," J. Dev. Econ., 1976, doi: 10.1016/0304-3878(76)90027-4.

[9] F. Cleaver, "The inequality of social capital and the reproduction of chronic poverty," World Dev., 2005, doi: 10.1016/j.worlddev.2004.09.015.

[10] M. Ayub, "Poverty and Inequality," Glob. J. Emerg. Mark. Econ., 2013, doi: 10.1177/0974910113505796.

[11] A. K. Giri and P. Quarles van Ufford, "A Moral Critique of Development: Ethics, Aesthetics and Responsibility," Rev. Dev. Chang., 2004, doi: 10.1177/0972266120040101.

[12] E. Fodor and D. Horn, "Economic development and gender equality: Explaining variations in the gender poverty gap after socialism," Social Problems. 2015, doi: 10.1093/socpro/spv007.

[13] J. D. Sachs, "From millennium development goals to sustainable development goals," The Lancet. 2012, doi: 10.1016/S0140-6736(12)60685-0.

[14] V. K. Krůtilová and N. Hazuchová, "Poverty predictors in the Czech Republic: Do health predictors also matter?," J. Poverty Soc. Justice, 2019, doi: 10.1332/175982718X15407227620385.

[15] A. Senadjki and J. Sulaiman, "An empirical study on the influence of Islamic values in poverty alleviation," J. Islam. Account. Bus. Res., 2015, doi: 10.1108/JIABR-05-20120027.

[16] A. M. Sadeq, "Poverty Alleviation: An Islamic Perspective," Humanomics. 1997, doi: 10.1108/eb018797.

[17] R. Sasmal and J. Sasmal, "Public expenditure, economic growth and poverty alleviation," International Journal of Social Economics. 2016, doi: 10.1108/IJSE-082014-0161.

[18] J. Hussain, S. Mahmood, and J. Scott, "Gender, Microcredit and Poverty Alleviation in a Developing Country: The Case of Women Entrepreneurs in Pakistan," J. Int. Dev., 2019, doi: 10.1002/jid.3403.

[19] K. B. H. Miled and J.-E. Ben Rejeb, "Microfinance and Poverty Reduction: A Review and Synthesis of Empirical Evidence," Procedia - Soc. Behav. Sci., 2015, doi: 10.1016/j.sbspro.2015.06.339. 
[20] D. P. Aldrich and M. A. Meyer, "Social Capital and Community Resilience," Am. Behav. Sci., 2015, doi: 10.1177/0002764214550299.

[21] G. De Luca and M. Verpoorten, "Civil war, social capital and resilience in Uganda," Oxf. Econ. Pap., 2015, doi: 10.1093/oep/gpv036.

[22] T. Rockenbauch and P. Sakdapolrak, "Social networks and the resilience of rural communities in the Global South: A critical review and conceptual reflections," Ecol. Soc., 2017, doi: 10.5751/ES-09009-220110.

[23] E. G. Carayannis and D. F. J. Campbell, "Triple Helix, Quadruple Helix and Quintuple Helix and How Do Knowledge, Innovation and the Environment Relate To Each Other?," Int. J. Soc. Ecol. Sustain. Dev., 2010, doi: 10.4018/jsesd.2010010105.

[24] C. Wahyudi and B. Noorsetya, "The Power of Inclusive Interaction in Resolving The Religious Conflict (An Interactional Case of JAI, NU, and Muhammadiyah Activists in Bandung City)," KARSA J. Soc. Islam. Cult., 2017, doi: 10.19105/karsa.v25i2.1414.

[25] C. Colapinto and C. Porlezza, "Innovation in Creative Industries: From the Quadruple Helix Model to the Systems Theory," J. Knowl. Econ., 2012, doi: 10.1007/s13132-0110051-x. 